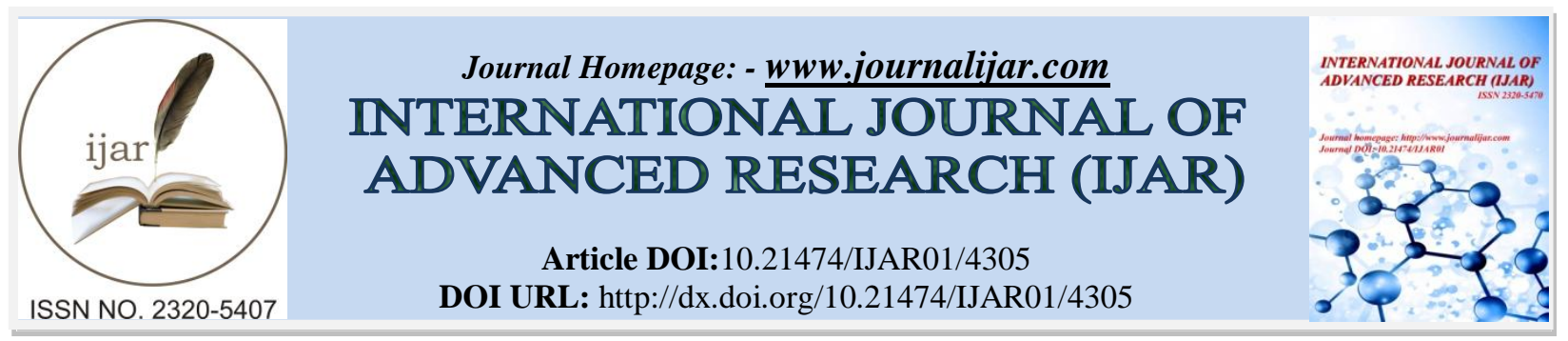

RESEARCH ARTICLE

\title{
STRENGTHENING SUPPLY CHAIN MANAGEMENT PRACTICES THROUGH INTEGRATION OF BUYER-SUPPLIER RELATIONSHIP ACROSS SMEs.
}

\author{
Dr. Gaurav Sehgal. \\ Associate Professor \& Head, Department of Marketing and Supply Chain Management, Central University of \\ Jammu, Jammu, J\&K State.
}

\section{Manuscript Info}

.

\section{Manuscript History}

Received: 20 March 2017

Final Accepted: 25 April 2017

Published: May 2017

Key words:-

SCM, SMEs, Buyer-Supplier, Perceived

Benefits, Supply Chain Integration

\section{Abstract}

Firms can no longer effectively compete in isolation of their suppliers and other entities in the supply chain. As organizations seek to develop partnerships and more effective information links with trading partners, internal processes become interlinked and span the traditional boundaries of firms. The SMEs' view of SCM seems to be the exertion of power by customers and consequently is seen by SMEs' as a one -way process. Similarly, SMEs' do not employ SCM; rather they are managed at arm's length by large customers. The choice of organization's environment is a driver to SME organization's growth. SMEs' grow by pursuing a differentiated strategy and progressing through discrete stages of growth and consequently the ability of the entrepreneur to make structural and strategic changes may determine the growth prospects of business. However, supply chain integration is essential for sustainability in any organization which accounts for all activities within an organization and the activities of its suppliers, customers and other supply chain members, to be integrated together. Supply chain integration links a firm with its customers, suppliers and other channel members by integrating their relationships, activities, functions, processes and locations. Having an integrated supply chain provides significant competitive advantage including the ability to outperform rivals on both price and delivery. Supply chain integration includes two stages: internal integration between functions and external integration with trading partners. The objective of this paper is to find out the impact of buyer-supplier relationship on the effectiveness of Practices of Supply Chain Management of the firm especially SMEs. The sample frame for this paper has been SMEs of Jammu District in J\&K State.

Copy Right, IJAR, 2017,. All rights reserved.

\section{Introduction:-}

Efficient SCM demands transparency for inventory and deliveries along the whole supply network. Material flow transparency, specifically the visibility to inventories and deliveries in the whole supply network, is considered an imperative requirement for successful SCM, and has been associated with significant supply chain efficiency improvements through long-terms buyer-supplier relationships (Gunasekaran and Ngai, 2004). Supply Chain network is the interrelated accumulation of techniques and related assets that starts with the obtaining of raw 
material and stretches out to the delivery of end items to the customers. It incorporates suppliers, producers, logistics management suppliers, storehouses, wholesalers, and all different constituents that pave the way to transportation to the last customer. From a broader point of view it might also incorporate the suppliers to the merchants and the customers of the fast clients. For regular sections of transactions and operations, the production network is quite limited and ranges out from obtaining the finished merchandise from the assembling workplaces to supplying the fast clients. However in a more driven operations it may stretch out to the client of the prompt client. In this period of there is a dire need for every organization to secure themselves with the key elements of innovation and competition. Successful Supply Chain Management (SCM) accommodates a completely integrative methodology: workers, methods, innovation, capacities and even supply system assists the needs which are completely adjusted and synchronized so as to construct capacity. Such an assistances consequently increases chances of sustainability. This research paper tries to address these issues in connection with the Small and Medium Enterprises (SMEs).

\section{Review of Literature:-}

Two influential source books that define principles and practice of supply chain management are The Goal (Goldratt, Eliyahu M., 1984, The Goal, Great Barrington, MA: The North River Press Publishing Corporation); and Supply Chain Management: Strategy, Planning, and Operation by Sunil Chopra and Peter Meindl. The Goal explores the issues and provides answers to the problem of optimizing operations in any business system whether it be manufacturing, mortgage loan processing or supply chain management.

The goal or mission of supply chain management can be defined using Mr. Goldratt's words as "Increase throughput while simultaneously reducing both inventory and operating expense." In this definition throughput refers to the rate at which sales to the end customer occur. Depending on the market being served, sales or throughput occurs for different reasons. In some markets customers value and will pay for high levels of service, while in other markets customers seek simply the lowest price for an item. There are five areas where companies can make decisions that will define their supply chain capabilities include: Production; Inventory; Location; Transportation; and Information. Chopra and Meindl define these areas as performance drivers that can be managed to produce the capabilities needed for a given supply chain. Effective supply chain management calls first for an understanding of each of these drivers and how it operates. Each driver has the ability to directly affect the supply chain and enable certain capabilities.

\section{Research Methodology:-}

Perceived benefits refer to the level of recognition of the relative advantage that SCM can provide to the organization. Many practitioners and researchers have attempted to identify the potential advantages that knowledge management system has to offer. Pfeiffer (1992) and Iacovou et al. (1995) argued that these perceived benefits can be understood from two perspectives. The first perspective looks at the direct benefits from SCM. These are mostly operational improvements in organizational knowledge management capabilities that the firm believes SCM can bring. Therefore one's understanding to firm's perceived knowledge management capability improvement is based on the five activities of the generic knowledge management process identified by Cormican and O'Sullivan (2003), that is, firm's capabilities on supply chain knowledge generation, storage, access, dissemination and application are all expected to be facilitated by SCM practices.

The second perspective of perceived SCM benefits observes the indirect benefits or opportunities from implementing SCM. It explores to the impact of SCM on the overall organizational and supply chain performance dimensions. These are mostly tactical and competitive advantages the firm gains indirectly from implementing SCM. Although the ultimate benefits of implementing SCM can include large financial savings, better product / service offering, improve customer service etc, these benefits are too remote and too general to be analyzed.

\section{Theoretical Framework:-}

Supply Chain Management Practices (SCMP) has 20 items in 4 sub-dimensions: Supply Chain Performance (SCP) five items, Barrier Free Access (BFA) five items, Supply Chain Knowledge Dissemination (SCKD) four items and Supply Chain Practices Application (SCPA) six items. While Supply Chain Perceived Benefits for Buyer-Supplier Relationship (SCPB) is a single dimension construct measured by 14 items that are considered important for cordial relationship among trading partners for success of SCM Practices across the SMEs. 


\section{Hypothesis:-}

Since the goal of this research paper was to study the impact of Buyer-Supplier Relationship for reinforcing the supply chain management practices embraced by the firm particularly SMEs, accordingly, the accompanying hypotheses / assumption was formulated:

$\mathrm{H}_{1}$ : Failure of buyer-supplier relationship affect the proper implementation of Supply Chain Management Practices in SME's.

\section{Data Collection, Methodology and Instrument Administration:-}

In order to collect precise data, a reliable measurement instrument is needed. To ensure brevity, understandability and content validity of the items, a rigorous validation procedure was adopted for preliminary test. A survey instrument in the form of a questionnaire was designed based on the constructs and verified from the research methodology adopted for meeting the objectives stated for this research study. Respondents were asked to indicate, using a five-point Likert scale. To ensure a reasonable response rate the questionnaire was sent in two phases in each industrial hub with a three months interval. In the first phase the questionnaires were sent to all 450 respondents inviting them to participate in the study with a brief description of the research, stating that all data collected would be used for academic research only and be handled confidentially. The sample area for the presented paper included industrial hubs of Jammu only.

\section{Methodology:-}

As proposed by Gerbing and Anderson (1988), the research paper tests the estimation in order to avoid conceivable associations between the estimation and the structural models. Besides, a measure can't be legitimate unless it is solid, yet a measure can be dependable without being substantial. Bagozzi (1980) and Bagozzi\& Philips (1982) proposed an instrument assessment rule that the instrument properties for unwavering quality and legitimacy incorporate purging, component structure (starting legitimacy), uni-dimentionality, dependability and the approval of the second-order develop. The strategies for every examination were: Corrected-Item-to-Total-Correlation (for purging), Cronbach's Alpha (for dependability) and Confirmatory Factor Analysis (for first and second order element structure and uni-dimensionality).

The measurement items were first purified by using Corrected-Item-to-Total-Correlation (CITC) scores with respect to a specific dimension of the construct. Following the guidelines constructed by Nunnally (1978), an alpha score of higher than 0.70 for a construct is generally considered to be acceptable (Robinson et. al., 1991; Robinson and Shaver, 1973). The reliability analysis of IBM $^{\circledR}$ SPSS $^{\circledR} 19.0$ was used to perform CITC computation of each of the construct.

After purifying the items based on CITC, an Exploratory Factor Analysis (EFA) of the items in each construct was conducted for assessing construct dimensionality. IBM ${ }^{\circledR}$ SPSS $^{\circledR} 19.0$ was extensively used to explore potential latent sources of variance and covariance in the observed measurements. Principal Component Analysis (PCA) was used as factor extraction method and VARIMAX was selected as the factor rotation method. Also MEANSUB option was used in most cases to replace the missing values with the mean score for that item. All the items for each construct were EFA tested regardless for its existence in a proposed sub-dimension. To ensure high quality of instrument development process in the current study, 0.5 was used as the cut-off for factor loadings (Hair, et. al., 1992). The Kaiser-Meer-Olkin (KMO) measure of sampling adequacy was calculated for all dimension-level and constructlevel factor analysis. This measure ensures that the effective sample size is adequate for the current factor analysis. The next step after item purification is to examine the uni-dimentionality of the underlying latent constructs. Unidimentionality is the characteristic of a set of indicators that has only one underlying trait or concept in common (Hair et. al. 1998). CFA is used to determine the adequacy of the measurement model's goodness-of-fit to the sample data. Due to the robustness and flexibility of the Structural Equation Modeling (SEM) in establishing CFA, this research uses SEM to test both first-order as well as second-order CFA models. IBM ${ }^{\circledR}$ SPSS $^{\circledR}$ AMOS $^{\text {TM }} 19.0$ was used to perform SEM analysis. Model data fitting was evaluated based on multiple goodness-of-fit indexes. Goodness-of-fit measures the correspondence of the actual or observed input (covariance or correlation) matrix with that predicted from the proposed model. This study used reports of several measures of overall model fit from IBM ${ }^{\circledR}$ SPSS $^{\circledR}$ AMOS $^{\mathrm{TM}}$ 19.0, such as, Goodness-of-fit-index (GFI), Adjusted-goodness-of-fit-index (AGFI), Comparativefit-index (CFI), Normed-fit-index (NFI), Root-mean-square-residual (RMR) and Root-mean-square-error-ofapproximation (RMSEA). Finally, the reliability of the entire set of items comprising the second order constructs was estimated using Cronbach's alpha. Following the guideline established by Nunnally (1978), an Alpha score of higher than 0.50 is generally considered to be acceptable. 
Figure I:- Structural Model for proposed Hypotheses.

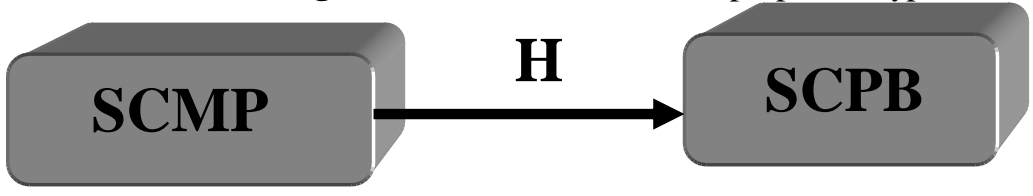

Figure II:-Structural Model for testing of Hypothesis $\left(\mathrm{H}_{1}\right)$.

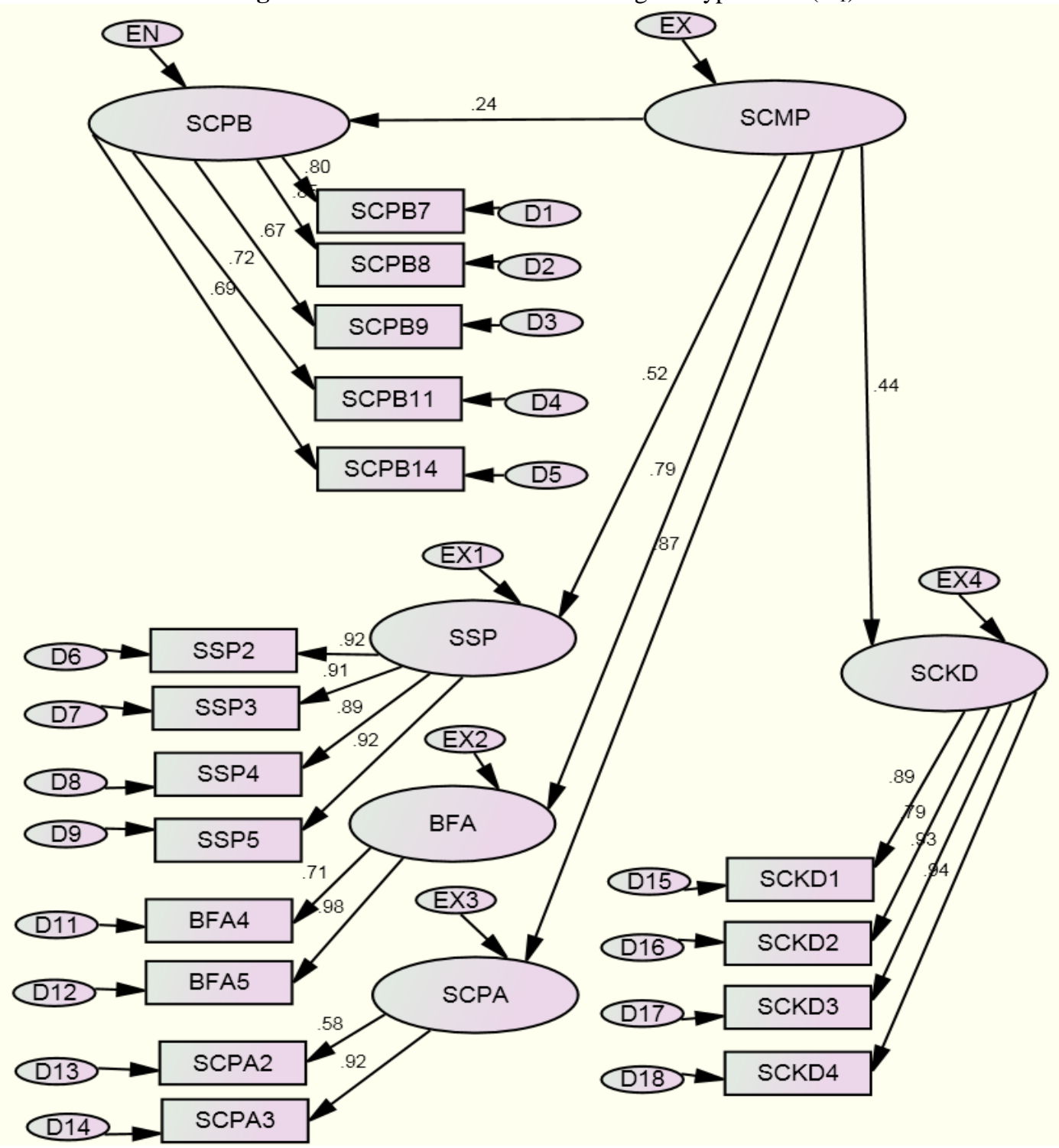

Table I:-CITC Item Purification results for Supply Chain Management Practices.

\begin{tabular}{|c|c|c|c|c|}
\hline \multicolumn{5}{|c|}{ Supply Chain Management Practices (SCMP) } \\
\hline Item Code & CITC Initial & $\begin{array}{c}\text { Cronbach's Alpha } \\
\text { - Initial }\end{array}$ & CITC Final & $\begin{array}{c}\text { Cronbach's Alpha } \\
\text { - Final }\end{array}$ \\
\hline SSP1 & 0.702 & \multirow[t]{5}{*}{0.925} & -- & \multirow[t]{5}{*}{0.925} \\
\hline SSP2 & 0.835 & & -- & \\
\hline SSP3 & 0.832 & & -- & \\
\hline SSP4 & 0.817 & & -- & \\
\hline SSP5 & 0.850 & & -- & \\
\hline
\end{tabular}




\begin{tabular}{|c|c|c|c|c|}
\hline BFA1 & 0.728 & \multirow[t]{5}{*}{0.932} & -- & \multirow[t]{5}{*}{0.932} \\
\hline BFA2 & 0.840 & & -- & \\
\hline BFA3 & 0.874 & & -- & \\
\hline BFA4 & 0.842 & & -- & \\
\hline BFA5 & 0.871 & & -- & \\
\hline SCKD1 & 0.814 & \multirow[t]{4}{*}{0.921} & -- & \multirow[t]{4}{*}{0.921} \\
\hline SCKD2 & 0.728 & & -- & \\
\hline SCKD3 & 0.866 & & -- & \\
\hline SCKD4 & 0.869 & & -- & \\
\hline SCPA1 & 0.586 & \multirow[t]{6}{*}{0.893} & -- & \multirow[t]{6}{*}{0.893} \\
\hline SCPA2 & 0.698 & & -- & \\
\hline SCPA3 & 0.788 & & -- & \\
\hline SCPA4 & 0.695 & & -- & \\
\hline SCPA5 & 0.764 & & -- & \\
\hline SCPA6 & 0.753 & & -- & \\
\hline
\end{tabular}

Table II:- EFA results for Supply Chain Management Practices.

\begin{tabular}{|c|c|c|c|c|c|}
\hline \multicolumn{6}{|c|}{ Kaiser-Meyer-Olkin (KMO) : Measure of Sampling Adequacy Score $=\mathbf{0 . 8 8 4}$} \\
\hline Item Code & SSP & BFA & SCKD & SCPA & Cronbach's Alpha \\
\hline SSP1 & 0.796 & & & & \multirow{5}{*}{0.925} \\
\hline SSP2 & 0.895 & & & & \\
\hline SSP3 & 0.892 & & & & \\
\hline SSP4 & 0.875 & & & & \\
\hline SSP5 & 0.902 & & & & \\
\hline BFA1 & & 0.763 & & & \multirow{5}{*}{0.932} \\
\hline BFA2 & & 0.882 & & & \\
\hline BFA3 & & 0.919 & & & \\
\hline BFA4 & & 0.901 & & & \\
\hline BFA5 & & 0.867 & & & \\
\hline SCKD1 & & & 0.898 & & \multirow{4}{*}{0.921} \\
\hline SCKD2 & & & 0.832 & & \\
\hline SCKD3 & & & 0.922 & & \\
\hline SCKD4 & & & 0.921 & & \\
\hline SCPA1 & & & & 0.709 & \multirow{6}{*}{0.893} \\
\hline SCPA2 & & & & 0.799 & \\
\hline SCPA3 & & & & 0.835 & \\
\hline SCPA4 & & & & 0.735 & \\
\hline SCPA5 & & & & 0.833 & \\
\hline SCPA6 & & & & 0.804 & \\
\hline Eigen Value & 7.908 & 3.744 & 3.144 & 0.871 & \\
\hline \%age of Variance & 39.540 & 18.722 & 15.719 & 4.354 & \\
\hline Cumulative \%age of Variance & 39.540 & 58.263 & 73.982 & 78.336 & \\
\hline
\end{tabular}

Table III:- First Order CFA model fit results for Supply Chain Management Practices.

\begin{tabular}{|c|c|c|c|c|c|c|c|c|c|}
\hline Model Fit & $\chi^{2}$ & df & $\chi^{2} /$ df & RMSEA & RMR & GFI & AGFI & NFI & CFI \\
\hline Initial & 1286.779 & 164 & 7.846 & 0.146 & 0.081 & 0.729 & 0.653 & 0.804 & 0.824 \\
\hline $\begin{array}{c}\text { After Removing } \\
\text { BFA1 }\end{array}$ & 877.013 & 146 & 6.007 & 0.125 & 0.073 & 0.771 & 0.703 & 0.852 & 0.873 \\
\hline $\begin{array}{c}\text { After Removing } \\
\text { BFA1, BFA3 }\end{array}$ & 640.790 & 129 & 4.967 & 0.111 & 0.070 & 0.815 & 0.754 & 0.875 & 0.897 \\
\hline $\begin{array}{c}\text { After Removing } \\
\text { BFA1, BFA3, } \\
\text { BFA2 }\end{array}$ & 455.053 & 113 & 4.027 & 0.097 & 0.070 & 0.846 & 0.791 & 0.899 & 0.921 \\
\hline After Removing & 304.717 & 98 & 3.109 & 0.081 & 0.062 & 0.897 & 0.857 & 0.925 & 0.947 \\
\hline
\end{tabular}




\begin{tabular}{|c|c|c|c|c|c|c|c|c|c|}
\hline $\begin{array}{l}\text { BFA1, BFA3, } \\
\text { BFA2, SCPA6 }\end{array}$ & & & & & & & & & \\
\hline $\begin{array}{c}\text { After Removing } \\
\text { BFA1, BFA3, } \\
\text { BFA2, SCPA4 }\end{array}$ & 198.817 & 84 & 2.367 & 0.065 & 0.056 & 0.926 & 0.894 & 0.947 & 0.969 \\
\hline $\begin{array}{c}\text { After Removing } \\
\text { BFA1, BFA3, } \\
\text { BFA2, SCPA1 }\end{array}$ & 148.053 & 71 & 2.085 & 0.058 & 0.045 & 0.942 & 0.914 & 0.958 & 0.978 \\
\hline
\end{tabular}

Table IV:- Second Order CFA model fit results for Supply Chain Management Practices

\begin{tabular}{|c|c|c|c|c|c|c|c|c|c|}
\hline Model Fit & $\boldsymbol{\chi}^{\mathbf{2}}$ & $\mathbf{d f}$ & $\boldsymbol{\chi}^{\mathbf{2}} / \mathbf{d f}$ & $\mathbf{R M S E A}$ & $\mathbf{R M R}$ & $\mathbf{G F I}$ & AGFI & NFI & CFI \\
\hline Initial & 360.737 & 76 & 4.747 & 0.108 & 0.291 & 0.851 & 0.794 & 0.899 & 0.918 \\
\hline $\begin{array}{c}\text { After Removing } \\
\text { SSP1 }\end{array}$ & 199.959 & 74 & 2.702 & 0.065 & 0.044 & 0.865 & 0.809 & 0.910 & 0.927 \\
\hline
\end{tabular}

Table V:- CITC Item Purification results for Supply Chain Perceived Benefits for Buyer-Supplier Relationship.

\begin{tabular}{|c|c|c|c|c|}
\hline \multicolumn{5}{|c|}{ Supply Chain Perceived Benefits for Supplier-Buyer Relationship (SCPB) } \\
\hline Item Code & CITC Initial & $\begin{array}{c}\text { Cronbach's Alpha } \\
\text { - Initial }\end{array}$ & CITC Final & $\begin{array}{c}\text { Cronbach's Alpha } \\
\text { - Final }\end{array}$ \\
\hline SCPB1 & 0.305 & \multirow[t]{14}{*}{$\mathbf{0 . 7 9 4}$} & Item Dropped & \multirow[t]{14}{*}{$\mathbf{0 . 8 9 0}$} \\
\hline SCPB2 & 0.271 & & Item Dropped & \\
\hline SCPB3 & 0.249 & & Item Dropped & \\
\hline SCPB4 & 0.044 & & Item Dropped & \\
\hline SCPB5 & 0.265 & & Item Dropped & \\
\hline SCPB6 & 0.377 & & Item Dropped & \\
\hline SCPB7 & 0.596 & & 0.727 & \\
\hline SCPB8 & 0.667 & & 0.758 & \\
\hline SCPB9 & 0.523 & & 0.608 & \\
\hline SCPB10 & 0.538 & & 0.638 & \\
\hline SCPB11 & 0.515 & & 0.707 & \\
\hline SCPB12 & 0.520 & & 0.656 & \\
\hline SCPB13 & 0.425 & & 0.546 & \\
\hline SCPB14 & 0.522 & & 0.696 & \\
\hline
\end{tabular}

Table VI:-EFA results for Supply Chain Perceived Benefits for Buyer-Supplier Relationship.

\begin{tabular}{|c|c|c|}
\hline \multicolumn{3}{|c|}{ First Iteration of EFA } \\
\hline \multicolumn{3}{|c|}{ Kaiser-Meyer-Olkin (KMO) : Measure of Sampling Adequacy Score = 0.904} \\
\hline Item Code & $\begin{array}{l}\text { Supply Chain Perceived Benefits for Buyer- } \\
\text { Supplier Relationship (SCPB) }\end{array}$ & Second Factor \\
\hline SCPB7 & 0.737 & -- \\
\hline SCPB8 & 0.782 & -- \\
\hline SCPB9 & 0.794 & -- \\
\hline SCPB10 & 0.831 & -- \\
\hline SCPB11 & 0.664 & -- \\
\hline SCPB12 & 0.789 & -- \\
\hline SCPB13 & 0.863 & 0.583 \\
\hline SCPB14 & 0.689 & -- \\
\hline Eigen Value & 4.554 & 1.035 \\
\hline \%age of Variance & 56.926 & 12.941 \\
\hline Cumulative \%age of Variance & 56.926 & 69.867 \\
\hline \multicolumn{3}{|c|}{ Second Iteration of EFA } \\
\hline \multicolumn{3}{|c|}{ Kaiser-Meyer-Olkin (KMO) : Measure of Sampling Adequacy Score = 0.896 } \\
\hline Item Code & $\begin{array}{c}\text { Supply Chain Perceived Benefits for Buyer- } \\
\text { Supplier Relationship (SCPB) }\end{array}$ & Second Factor \\
\hline
\end{tabular}




\begin{tabular}{|c|c|c|}
\hline SCPB7 & 0.821 & -- \\
\hline SCPB8 & 0.849 & -- \\
\hline SCPB9 & 0.731 & -- \\
\hline SCPB10 & 0.758 & -- \\
\hline SCPB11 & 0.775 & -- \\
\hline SCPB12 & 0.716 & -- \\
\hline SCPB14 & 0.767 & -- \\
\hline Eigen Value & $\mathbf{4 . 2 0 4}$ & -- \\
\hline \%age of Variance & $\mathbf{6 0 . 0 5 1}$ & -- \\
\hline
\end{tabular}

Table VII:- CFA model fit results for Supply Chain Perceived Benefits for Buyer-Supplier Relationship.

\begin{tabular}{|c|c|c|c|c|c|c|c|c|c|}
\hline Model Fit & $\chi^{2}$ & df & $\chi^{2} /$ df & RMSEA & RMR & GFI & AGFI & NFI & CFI \\
\hline Initial & 79.404 & 14 & 5.672 & 0.120 & 0.050 & 0.927 & 0.853 & 0.929 & 0.941 \\
\hline $\begin{array}{c}\text { After Removing } \\
\text { SCPB12 }\end{array}$ & 29.582 & 9 & 3.287 & 0.084 & 0.034 & 0.971 & 0.932 & 0.968 & 0.978 \\
\hline $\begin{array}{c}\text { After Removing } \\
\text { SCPB12, SCPB10 }\end{array}$ & 14.820 & 5 & 2.964 & 0.078 & 0.031 & 0.982 & 0.945 & 0.979 & 0.986 \\
\hline
\end{tabular}

TableVIII:- Structural model Hypothesis Testing Results.

\begin{tabular}{|c|c|c|c|c|c|}
\hline Hypotheses & Relationship & $\begin{array}{c}\text { Standardized } \\
\text { Estimate }\end{array}$ & t-value & p-value & $\begin{array}{c}\text { Significance } \\
\text { (Yes/No) }\end{array}$ \\
\hline $\mathbf{H}_{\mathbf{1}}$ & SCMP $\rightarrow$ SCPB & 0.24 & $=(0.391 / 0.107)=$ & $<0.05$ & YES \\
\hline
\end{tabular}

TableIX:- Parameters along with Coding used during Data Analysis.

\begin{tabular}{|c|c|c|c|c|}
\hline S.No. & $\begin{array}{l}\text { Category } \\
\text { Code }\end{array}$ & $\begin{array}{l}\text { Sub- } \\
\text { Category } \\
\text { Code }\end{array}$ & $\begin{array}{l}\text { Item } \\
\text { Code }\end{array}$ & Parameters \\
\hline 1. & \multirow{14}{*}{ 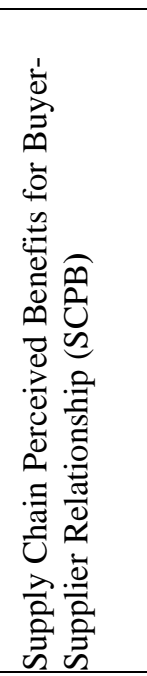 } & \multirow[t]{14}{*}{--} & SCPB1 & It improves our ability to create new SCM Practices. \\
\hline \multirow{2}{*}{2.} & & & SCPB2 & Improves our market credibility. \\
\hline & & & SCPB3 & Facilitates our relationship with our trading partners. \\
\hline 4. & & & SCPB4 & Improves our ability to explore market potential. \\
\hline 5. & & & SCPB5 & Enables us to make better business decisions. \\
\hline 6. & & & SCPB6 & Decreases our SCM handling costs. \\
\hline 7. & & & SCPB7 & Enhances our ability to innovate. \\
\hline 8. & & & SCPB8 & $\begin{array}{l}\begin{array}{l}\text { Improves our ability to handle exceptional business } \\
\text { circumstances. }\end{array} \\
\end{array}$ \\
\hline 9. & & & SCPB9 & Improves our firm's ability to adapt to environmental changes. \\
\hline 10. & & & SCPB10 & Facilitates business transactions with our suppliers. \\
\hline 11. & & & SCPB11 & Improves and facilitates collaboration across the supply chain. \\
\hline 12. & & & SCPB12 & Improves our ability to keep promises on deliveries. \\
\hline 13. & & & SCPB13 & Improves the overall business decision making model of our firm. \\
\hline 14. & & & SCPB14 & $\begin{array}{lllll}\text { Improves at building customer } / \text { supplier relationship } \\
\text { management in our firm. }\end{array}$ \\
\hline 15. & $\vec{\Xi}$ & $\ddot{气}$ & SSP1 & $\begin{array}{l}\text { Our firm implements SCM because with it our firm wishes to } \\
\text { collaborate on the benefits obtained from its usage. }\end{array}$ \\
\hline 16. & 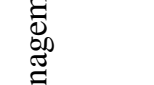 & 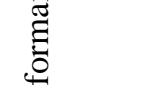 & SSP2 & $\begin{array}{l}\text { Our firm implements SCM because with it our firm wishes to } \\
\text { strengthen relationship with our trading partners. }\end{array}$ \\
\hline 17. & $\sum_{\Xi}^{\pi}$ & $\stackrel{\Xi}{ \pm}$ & SSP3 & $\begin{array}{l}\text { Our firm implements SCM because with it our firm believes that } \\
\text { our relationship with trading partner is profitable. }\end{array}$ \\
\hline 18. & $\underbrace{\mathbb{Z}}_{\triangle}$ & $\bigcup_{\lambda}^{\mathbb{Z}}$ & SSP4 & $\begin{array}{l}\text { Our firm implements SCM because with it our firm and our } \\
\text { trading partner can share risks that occur in SCM. }\end{array}$ \\
\hline 19. & 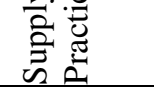 & 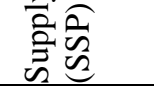 & SSP5 & $\begin{array}{l}\text { Our firm implements SCM because with it our firm can have } \\
\text { harmonious relationship with our trading partner. }\end{array}$ \\
\hline
\end{tabular}




\begin{tabular}{|c|c|c|c|}
\hline 20. & \multirow{5}{*}{ 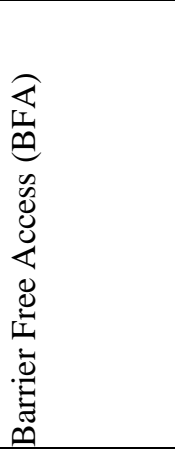 } & BFA1 & $\begin{array}{l}\text { Our firm believes that with SCM implementation our firm can } \\
\text { handle non-standard orders. }\end{array}$ \\
\hline 21. & & BFA2 & $\begin{array}{l}\text { Our firm believes that with SCM implementation our firm can } \\
\text { meet special customer requirements. }\end{array}$ \\
\hline 22. & & BFA3 & $\begin{array}{l}\text { Our firm believes that with SCM implementation our firm can } \\
\text { produce products with multiple features. }\end{array}$ \\
\hline 23. & & BFA4 & $\begin{array}{l}\text { Our firm believes that with SCM implementation our firm can } \\
\text { rapidly adjust to production capacity in response to the change in } \\
\text { customer demand. }\end{array}$ \\
\hline 24. & & BFA5 & $\begin{array}{l}\text { Our firm believes that with SCM implementation our firm can } \\
\text { introduce new products quickly. }\end{array}$ \\
\hline 25. & \multirow{4}{*}{ 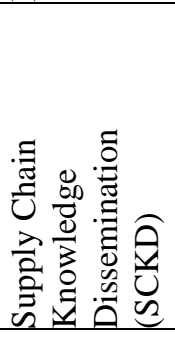 } & SCKD1 & $\begin{array}{l}\text { Our firm believes that with SCM implementation our firm can } \\
\text { help exchange information with our suppliers. }\end{array}$ \\
\hline 26. & & SCKD2 & $\begin{array}{l}\text { Our firm believes that with SCM implementation our firm can } \\
\text { help maintain long-term partnerships. }\end{array}$ \\
\hline 27. & & SCKD3 & $\begin{array}{l}\text { Our firm believes that with SCM implementation our firm can } \\
\text { help provide stable procurement relationships. }\end{array}$ \\
\hline 28. & & SCKD4 & $\begin{array}{l}\text { Our firm believes that with SCM implementation our firm can } \\
\text { share market information among departments within the firm. }\end{array}$ \\
\hline 29. & \multirow{6}{*}{ 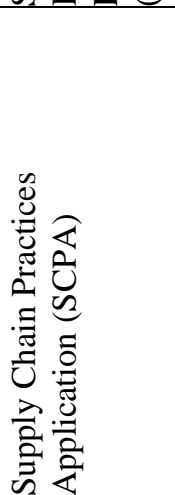 } & SCPA1 & $\begin{array}{l}\text { Our firm believes that with SCM applications help to have } \\
\text { integrated inventory management system. }\end{array}$ \\
\hline 30. & & SCPA2 & $\begin{array}{l}\text { Our firm believes that with SCM applications help to have } \\
\text { integrated logistics support system. }\end{array}$ \\
\hline 31. & & SCPA3 & $\begin{array}{l}\text { Our firm believes that with SCM applications help to have } \\
\text { automated order refilling system. }\end{array}$ \\
\hline 32. & & SCPA4 & $\begin{array}{l}\text { Our firm believes that with SCM applications help to have } \\
\text { automated accounting system. }\end{array}$ \\
\hline 33. & & SCPA5 & $\begin{array}{l}\text { Our firm believes that with SCM applications help to have } \\
\text { integrated data sharing system. }\end{array}$ \\
\hline 34. & & SCPA6 & $\begin{array}{l}\text { Our firm believes that with SCM applications help to have } \\
\text { synchronized production schedules. }\end{array}$ \\
\hline
\end{tabular}

\section{Research Findings and Discussions:-}

\section{Supply Chain Management Practices:-}

The CITC analysis revealed that it had a perfect Cronbach's $\alpha$ value (0.900). Furthermore, separate CITC analysis revealed that no item in each of the sub-constructs were below the CITC cut-off of 0.5. The CITC for each item with its corresponding code name are shown in Table-I.

In the next step EFA was performed using principal component as means of extraction and VARIMAX as method of rotation. The KMO score of 0.884 indicated a good sampling adequacy. All items load on their respective factors and the result showed no cross-loadings. The EFA results have been tabulated in Table-II.

The results indicated that although factor loading coefficients for the initial model were greater than 0.60 with the least at 0.67 for item SCPA4, but the model fit was having poor indices: $\chi^{2} / \mathrm{df}=7.846$; RMSEA $=0.146$; RMR= $0.081 ; \mathrm{GFI}=0.729 ; \mathrm{AGFI}=0.653 ; \mathrm{NFI}=0.804$ and $\mathrm{CFI}=0.824$; henceforth modification indices were utilized for modifications in the model which indicated a chance for model improvement as a result from possibility of error correlation (as shown in Table-III), after removing the correlated affects the final first-order CFA model was thus obtained. Thereafter, modification indices indicated that there was no need for any modifications in the model constructs. The first-order CFA model for Supply Chain Management Practices (SCMP) clearly showed that the factor loadings $(\lambda)$ were acceptable with the lowest being 0.73 for the item SSP1.

In the next step, the second order model was tested to see if these four sub-constructs (SSP, BFA, SCKD\& SCPA) underlie a single high order construct of SCMP. It was observed that high-order correlated effect was observed for SSP1; hence this item of the sub-construct was deleted from the study model. The resulting second-order CFA 
model for SCMP was therefore obtained which reflected that no further modification in the model was desired. The resultant goodness-of-fit indices for the second-order construct are as illustrated in Table-IV.

\section{Supply Chain Perceived Benefits for Buyer-Supplier Relationship:-}

CITC scores indicates that Cronbach's Alpha is 0.794, which though acceptable but most of the items of the construct were well below the cut-off value of 0.5, such as, SCPB1 (0.305), SCPB2 (0.271), SCPB3 (0.249), SCPB4 (0.044), SCPB5 (0.265), SCPB6 (0.377), SCPB13 (0.425). It was understood that one item needs to be deleted at a time to look into its scale of variance. But the item SCPB13 was retained at the Cronbach's Alpha value of 0.425 even though it was less than the cut-off value of 0.5 because of the importance of the item for the study. After multiple iterations CITC score for the dimension came to be 0.890 which was quite good to be accepted for the study. A total of six iterations were performed for obtaining this CITC score. The CITC for each item with its corresponding code name are shown in Table-V.

The next step is to test the 4 items of in Complementary Factor Analysis (CFA) for measurement of model fit. An Exploratory Factor Analysis (EFA) was then conducted using principal components as means of extraction. The Kaiser-Meyer-Olkin (KMO) score of 0.904 indicated a perfect sampling adequacy. The analysis demonstrated that two factors were extracted with cumulative variance of $56.926 \% \& 69.867 \%$. One item that was loaded on the second factor at SCPB13 had serious cross loading with the first factor; thus item SCPB13 was removed from the model. The second iteration of EFA with 7 items was conducted, extracting a single factor explaining $60.051 \%$ of total variance and $\mathrm{KMO}$ score at 0.896 . The EFA results are as shown in Table-VI.

The next step is to test the 7 items of SCPB in Complementary Factor Analysis (CFA) for measurement model fit. The CFA model for SCPB was then tested using IBM ${ }^{\circledR} \operatorname{SPSS}^{\circledR}$ AMOS $^{\mathrm{TM}} 19.0$. The results indicated poor model fit indices: $\chi^{2} / \mathrm{df}=5.672 ; \mathrm{RMSEA}=0.120 ; \mathrm{RMR}=0.050 ; \mathrm{GFI}=0.927 ; \mathrm{AGFI}=0.853 ; \mathrm{NFI}=0.929$ and $\mathrm{CFI}=0.941$; thus modification indices were utilized for calculating the high error correlated factors which came out to be SCPB12 (22.95). Items were therefore removed iteratively one by one from the analysis. After these items were removed, the model fit showed that there was no need for any modifications in the model constructs. The model for SCPB thus obtained showed that all the factor loadings $(\lambda)$ were above 0.50 and significantly important with the lowest being 0.67 for SCPB9. The model fit indices for SCPB is shown in Table-VII.

\section{Structural Model for Hypothesis:-}

For the structural model for hypothesis $\mathrm{H}_{1}$ (Figure-I), the constructs Perceived benefits of Supply Chain Management from Buyer-Supplier Relationship (SCPB) has been regarded as Independent Variables (Exogenous); whereas Supply Chain Management Practices Implementation (SCMP) has been regarded as Dependent Variable (Endogenous).

The model was developed utilizing one-tail test wherein a t-value more than 2.33 is considered critical at the level of 0.01 ; and a t-value more than 1.65 is considered acceptable at 0.05 ; and a t-value of 1.28 is acceptable at the level of 0.10 . The $\mathrm{t}$-value is ascertained from the assessments of the model, where $\mathrm{t}$-value is given as model path estimate (parameter) divided by the standard error. The outcomes for the proposed speculations and suggestions are as given in Table-VIII.

The structural model for the proposed hypothesis is as presented in Figure-II.

\section{Conclusion:-}

As expected, this hypothesis was also supported with a weak model relationship strength of 0.24 and $\mathrm{t}$-value $=$ 3.654. The ultimate objective of all supply chain management activities is to improve the supply chain relationship as well as enhance performance. The finding demonstrated that implementation of supply chain management practices improved the overall relationship with trading partners, this is to say that, such an act of SMEs has direct and tangible effects on improving supply chain relationship, system flexibility to internal and external changes, responsiveness to customer requirements and so on. It was also observed through the results that using SCM Practices can instill inspiration among the agents or SMEs for its effective usage in the firm. SMEs can undoubtedly lessen their trouble of money related and stock vacillations with appropriate relationship building conduct towards their trading partners. The SMEs must attempt to assess their business surroundings and ought to comprehend that the other's learning (trading partners) must be diverse to some degree, however the same if adjusted and comprehended can help smoothen the stream of budgetary and stock conditions within the firm. In the present 
competitive business world, SMEs must have an overall control over the changes as regards to funds and stock administration and subsequently influence the ability of the whole assembly network to work successfully. The study affirmed that presently the SMEs have an over-dependence on their money related and additionally stock management practices.

\section{References:-}

1. Alavi, M., and Leidner, D. E. (2001). Review: Knowledge management and knowledge management systems: Conceptual foundations and research issues. MIS Quarterly, 25(1), pp. 107-136.

2. Anderson, J. R. (1983). A spreading activation theory of memory. Journal of Verbal Learning and Verbal Behavior, 22, pp. 261-295.

3. Beamon, R. M., (1998). Supply chain design and analysis: Models and methods. International Journal of Production Economics, 55, pp. 281-294.

4. Bagozzi R.P. (1980). A Causal Model in Marketing. New York, Wiley.

5. Bagozzi R.P. and Philips L.W. (1982). Representing and testing organizational theories: A holistic construal. Administrative Science Quarterly, 27, pp.459-89.

6. Balsmierer, P. W. Voisin, W. (1996). Supply Chain Management; A time based strategy. Industrial Management, 38(5), pp.24-27.

7. Cormican, K and O'Sullivan, D, A (2003). Collaborative knowledge management tool for product innovation management. International Journal of Technology Management, 26(1), pp. 53-68.

8. Garwood, D. (1999). Supply Chain Management: New paradigms for customers and suppliers. Hospital Materials Management Quarterly, 20(3), pp-1-3.

9. Gaurav Sehgal (2012). Unpublished Research Work of Doctoral Thesis submitted to University of Jammu as Ph.D. Thesis.

10. Gerbing, D.W. and Anderson, J.C. (1988). An Upgraded for Scale Development incorporating Unidimensionality and its Assessment. Journal of Marketing Research, 25, pp.186-192.

11. Gunasekaran, A. and Ngai, E.W.T. (2003). The successful management of a small logistics company. International Journal of Physical Distribution and Logistics Management, Vol. 33 No. 9, pp. 825-42.

12. Hair, J.F., Anderson, R.E., Tatham, R.L., and Black, W.C. (1998). Multivariate Data Analysis. Fifth Edition, Macmillan Publishing Company, New York, NY.

13. Harland, C. M. (1996). Supply Chain Management: Relationships, Chains and Networks. British. Journal of Management, 7, pp.63-80.

14. Iaconou, C., Benbasat, I., and Dexter, A. (1995). EDI and small organizations: Adoption and impact of technology. MIS Quarterly, December; -p-p 465-485.

15. Kaun, Khan and Chau P (2001). A perception-based model of EDI adoption in small businesses using technology-organization-environment framework. Information and Management, 38, pp. 507-521.

16. Narasimhan, R. and Jayaram, J. (1998). Causal linkages in supply chain management: An exploratory study of North American manufacturing firms. Decision Sciences, 29(3), pp. 579-605.

17. Nikolaeva, R (2006). E-commerce adoption in the retail sector: empirical insights. International. Journal of Retail \& Distribution Management, 34(4/5), pp.369-387.

18. Nunnally, J.C. (1978). Psychometric Theory. McGraw Hill, New York.

19. Pfeiffer, H. (1992). The Diffusion of Electronics Data Interchange. Springer-Verlag, New York.

20. Pinsonneault, A. and Kraemer, K. (1993). Survey research methodology in management information systems: An assessment. Journal of Management Information Systems. 10(2), pp. 75-105.

21. Spekman, R., Salmond, D. and Kamauff, J., (1994). At Last Procurement Becomes Strategic. Long-Range Planning, 27(2), pp.76-84.

22. Spekman, R. P, J. W. Jr and Myhr, N. (1998). An empirical investigation into supply chain management: A perspective on partnerships. Supply Chain Management, 3(2), pp.53-67.

23. Stevens, G.C. (1989). Integrating the supply chain. International Journal of Physical Distribution and Materials Management, 19(8), pp.3-8.

24. Zhu, K. and Weyant, K. (2003). Strategic decisions of new technology adoption under asymmetrical information. Decision Sciences, 34(4), pp.643-675. 